\title{
Effect of Certain Insecticide on Interspecific Diversity and Equitability Which Used in Control Spodoptera littoralis on Berssem Crop under Assiut Governrate Conditions
}

\author{
O.A.A. Zedan and R.A.E. Ali
}

Plant Protection Department, Faculty of Agriculture, Al-Azhar University, Assiut

*Corresponding author: rabee8104@gmail.com

Received on: $15 / 8 / 2018$

Accepted for publication on: 23/10/2018

\begin{abstract}
This work was carried out during 2017 Berseem growing season to evaluate the effectiveness of chlorantraniliprole (coragen), emamectin benzoate (proclaim), profenofos (Cord 72\% EC), spinosad 24\% E.C and chloropyrifos 24\% (Chlorosan) as foliar applications at the recommended rate against the cotton leafworm, S. littoralis (Boisd.) on Egyptian clover plants. Also, Survey of insect pests and natural enemies associated with Egyptian clover, or berseem, Trifolium alexandrinum plants were conducted to study the side effects of insecticides on interspecific diversity and equitability of entomophagous after application with the tested compounds. Results showed that, the average reduction percentages after applications against $S$. littoralis were $75.8 \%$ for coragen, $68.7 \%$ for cord, $65.9 \%$ for proclaim, $57.3 \%$ for chlorosan, and 52.4\% for spinosad. Spodoptera littoralis, bollworms and Aphis gossbii are very important species which cause economic loss in the Berseem crop. Coccinella undecimpunctata, Trichogramma toide app, Apis mellifera L and Vespa orientalis were the most important natural enemies and pollinators which associated with Berseem plants. The diversity index value after application with proclaim and spinosad were higher in the application with the insecticides followed by cord, chlorpyriphos and coragen, respectivily. The result of proclaim showed high selectivity when compared with the other pesticides. As for equitability it is obvious that the compared with the other of equitability higher values in the treatment of proclaim especially after 3 weeks post treatment. The value of equitability reachd an environmental maximum. In conclusion, it could be suggested that Proclaim showed toxic effect against bollworms and had a selective effect on the beneficial insects in Egyptian clover, $T$. alexandrinum.
\end{abstract}

Keyword: Interspecific Diversity, equitability, Berseem.

\section{Introduction}

Egyptian clover or berseem clover (Trifolium alexandrinum L.) is leguminous forage species well adapted to semi-arid conditions of the Mediterranean areas (Iannucci et al. 1996). It is extensively accepted due to its multi-cut nature, quick regrowth with high fodder yield and provides the nutritious fodder to livestock from
November to April. Berseem is very popular among the dairy people and successfully can be grown all over the world under irrigated condition. Berseem can mitigate the shortage of the green fodder during the winter. Berseem known as trap crop for natural enemies which attract the predators and parasitoids. It also grown be side the main crop to enhance the 
natural enemies. The irrational use of pesticides reduced pests and natural enemies as well as crop come under stresses and yield decreases. (Wagan et al., 2014b). Several pesticide resistance problems have been found in area were the injudicious chemical poisons are applying for pest control (Rueda and Shelton, 1995). The rapid increase in pesticide consumption has destroyed the delicate balance between predators and pests in berseem growing areas. The best example is major outbreak of the tobacco caterpillar, Spodoptera littura (Fabricius) as regular polyphagous pest on the field and horticultural crops (Shankaramurthy et al., 2006). S. litura has emerged as a serious pest causing enormous loss of many economically important cultivated crops such as cotton, soybean, groundnut, tobacco, vegetables etc. (Qin et al., 2004). Fletcher, (1919) revealed that cabbage cauliflower, jute, potato leaves, raddish, sweet potato, lucerne, groundnut, pigeonpea, rose, celery, poppy, apple, onion, tea and cotton were seriously damaged by $S$. litura in Egypt. The major host plants of $S$. litura include tobacco, cotton, groundnut, sunflower, castor, lucerne, berseem, maize, chilli, potato, sweet potato, soybean, cauliflower, cabbage, tomato, beans and also ornamentals, weeds and wild plants in India and Pakistan.

The present study was performed to cover the following points, toxicological studies on the tested pesticides against cotton leaf-worm $S$. littoralis, behavioure of these compounds in Egyptian clover ecosystem by studying their effect on cotton bollworm, diversity and equitability of the community in Egyptian clover ecosystem after applying these pesticides.

\section{Materials and Methods}

Field investigation was carried out to evaluate the toxicity of insecticides chlorantraniliprole (coragen), emamectin benzoate (proclaim), profenofos (Cord 72\% EC), spinosad 24 $\%$ E.C and chloropyrifos $24 \%$ (chlorosan) on the insect pest and natural enemies in agro ecosystem of berseem field areas. A field trial was conducted at Fodder Research of Faculty of Agriculture AL-Azhar University Assiut, in growing season 2017.

\subsection{The tested insecticides}

Table 1. Active ingredients, Trade name, Company and application rate of the tested compounds.

\begin{tabular}{|l|c|c|c|}
\hline Active ingredient & Trade name & Company & Rate/Fed \\
\hline chlorantraniliprole & Coragen SC \%20 & DuPont de Nemours & $60 \mathrm{ml}$ \\
\hline emamectin benzoate & Proclaim $₫ 5 \%$ SG & Syngenta & $80 \mathrm{gm}$ \\
\hline profenofos 72\% EC & Cord & AL-HELB & $750 \mathrm{ml}$ \\
\hline spinosad 24 \% E.C & Spinosad & Dow-Agroscience & $60 \mathrm{ml}$ \\
\hline chloropyrifos 48\%EC & Chlorosan & $\begin{array}{c}\text { Kafer El-Ziat for Pesticides } \\
\text { \& Chemicals Co., Kafer, Egypt }\end{array}$ & $1 \mathrm{~L}$ \\
\hline
\end{tabular}

\subsubsection{Sampling technique}

The experimental area was divided into small plots (a plot size of
$3 \times 5 \mathrm{~m})$ each plot was separated from each other by 1 meter of bare ground. Randomized complete block design 
was followed in the whole experimentation area, and each treatment was replicated three times. The barseem crop harvested when the insect pest attack was severed, crop debris and weeds were burned after harvesting and land was ploughed 3 times before the sowing of barseem. Barseem seeds $25 \mathrm{Kg} /$ ha broad cast in irrigated soil beds on $19^{\text {th }}$ October, the germinations were completed in 5 days. Only urea fertilizer (40kg N/ha) was applied after 20 days of germinations and every 30 days of intervals (10 days after each cutting). Crop was irrigated by canal water on every 10 days interval during hot weather and 15days interval in cool weather. Variety SB-11 of berseem that was left for seed production after last cutting on $31^{\text {th }}$ March, 2017. Data collection was investigated after 14 days of germinations for pest and natural enemies on every week and 13 week were recorded throughout the three cutting periods, 50 plants were checked at every randomly selected locations spread throughout the field from the inner rows. The crop was observed early in the morning when all insects were passive.

\subsection{Spraying technique}

The amount of water required to provide sufficient spray liquid was found to be 250 liters/fed. The insecticides were chlorantraniliprole, emamectin benzoate, profenofos $72 \%$ EC, spinosad $24 \%$ E.C and chloropyrifos 24 witch sprayed by knapsack sprayer. The crop was regularly observed to measure the larval abundance of $S$. littoralis at 7 days interval. When the attack of young larvae of the insect was observed in the field, the crop was subjected to insec- ticide spray. For determination of quantity of water, calibration was done by spraying water in the nontreated plots. All the insecticides were sprayed after 5.30 PM to save pollinators, especially, honey bees. Before the application of each insecticide, the spray machine was cleaned thoroughly with clean water to avoid insecticide mixture. Larval population was recorded before and after treatment from one square meters from each plot in different treatments. Percent mortality was calculated by using the below mentioned formula the sprays were applied during experiment $5^{\text {th }}$ May (2017) when the infestation percent was reached to $5 \%$.

2.2. Survey of insect pest and natural enemies associated with Egyptian clover fields

The following methods were used to determine the effect of tested compounds on the populations of pests and beneficial arthropods in Egyptian clover fields ecosystem. Sampling start as soon as plants appeared above ground. Number of different life stages of pests and nature enemies were recorded weekly with 5 methods as follows:

2.2.1-Direct counts of different stages of different pests and predators on 50 plants $/$ plot

2.2.2- Water traps blue dishes filled with water and soft soap was used, all insects were colleted and identified

2.2.3- Pitfall traps contain $500 \mathrm{ml}$ ethyl alcohol $+100 \mathrm{ml}$ kerosene was used to determine the population of species that crawling on the soil surface. One trap/plot was used and plaed for 1 week. The arthropods 
were extracted from traps and identified.

2.2.4- Sticky traps: yellowchrome visual traps, glued with the adhesive "TemoBi" obtained from Kollant industrial chemical S.P.A. Italy were used. Coloured plastic plates $10 \times 15 \mathrm{~cm}$, on which a thin layer of adhesive was applied. Traps were mounted on a wooden support, $50 \mathrm{~cm}$ above the soil surface. A single trap was used for each plot. The traps were examined weekly, and the identification was made up to genus and in some cases at species level.

\subsection{5- Sweep net catch:}

A sweep net $(37 \mathrm{~cm}$ diameter was used to collect arthropod predators in barseem fields) 4 double sweep/plot to one replicate in all treatments intervals were carried. Samples were taken weekly and inspected using a binocular microscope for later identification and the fauna was sorted. Counts were calculated and expressed as total of insects from the two methods/plot. The samples insect species collected from different fields during blooming periods of the whole season of 2017. An area of one feddan was cultivated with each crop, these areas received usual agriculture practiced but no chemical. The collected species were identified to the possible lowest taxonomic level and examined using binocular microscope (National DC3-420T Digital Microscope) and a digital camera.

2.3. Determination of bollworm infestation after application insecticides in barseem fields.

Samples of 50 green plants were collected at two random from both diagonals of each plot to assess the cotton bollworm infestation and the numbers of pink and spiny bollworms larvae. A total of 150 green plants/ treatment were externally and internally examined. The sampling procedure was conducted on the pretreatment and 7,14 and 21 day post treatments in the two treatments. Percentage reduction in infestation was made according to Henderson and Telton formula (1955).

2.3. Interspecific diversity and equitability of entomophagous cyanosis after application of insecticides in Barseem ecosystem:

In order to asses the degree of influence by different insecticides in alternating the organization of entomophagous complex. Two ecological parameters were used the interspecific diversity and equitability. The diversity is a complex index of the structure of a system including the quantitative relationship between the numbers of species and numbers of individuals available within them. A commonly used index of diversity is $\left(\mathrm{H}^{\prime}\right)$ known as the Shannon -wiener index (1959).

$$
\left(\mathbf{H}^{\prime}\right)=\sum_{\mathbf{1}-\mathbf{i e}}^{\mathrm{a}}
$$

where:

$\mathbf{H}^{\prime}=$ diversity index, $\mathbf{a}=$ number of species $\mathbf{P i}=\mathbf{n} / \mathbf{N}$ where, $\mathbf{n}=$ number of individuals of one species. $\mathbf{N}=$ number of individuals of all species.

To express the way of individual's distribution in various components of the entomophagous cyanoses co-existing the tested variant, the second structure index, i.e. the equitability (E) was used and calculated according to Lioyd and Ghelradi, (1964) as follows:

$$
\mathbf{E}=\mathbf{S}^{`} / \mathbf{S} \times \mathbf{1 0 0}
$$

where : $\mathbf{E}=$ size of equitability $\mathbf{S}^{\backslash}=$ theoretical numbers of species $\mathbf{S}=$ number of observed species. 


\section{Result and Discussion}

\subsection{Survey of insect pests and} natural enemies associated with Egyptian clover fields:

Results in Table (2) show the common insects encountered in Egyptian clover fields, which may be divided into three groups, the first group is the natural enemies which include Sphodromantis virides, Sphodromantis pioculate, Apanteles spp. Trichogramma evanescens, Euprepocnemis plorans, Coccinella septempunctata and Coccinella undecimpunctata. The second group is the insect pestes which includes Bruchidius trifolii, Phytonoms bruneipennis, Nezara viridula, Spodoptera littoralis, Agrotis epsilon and Aphis gossbii. The third group is the pollinators including all of which belong to order of Hymenoptera family. The most important families were Apida and Andrenidae and many species of true spiders. These results are in agreement with results obtained by Shawer et al. (1989) who reported that the main pollinators of clover, in Kafr EL-Sheikh governorate, Egypt, were honeybees, and wild bees belong to family Andrenidae. While, Atallah et al. (1997), surveyed insect pollinators in Qena Governorate, Egypt and found that 49 insect species, belonging to 21 insect families, were surveyed. Most abundant species (30) were hymenopterous insects, followed by dipterous insects. The main pollinator of studied plants (seasame, clover, maize and broad bean) was honeybees, followed by wild bees. Tufail, et al. (2015) stud- ied the insect pests, which appear on berseem crop, and found: Whitefly, aphid, leaf minor, thrip, bug, cutworm and dusky Cricket. These populations were varied from one to another through whole study period Cutworm was the main seedling pest of berseem and vegetable in dry soil, the full occurrence on berseem was $1 /$ spot, during $2^{\text {nd }}$ week of observation, and overall average population 0.49 spot was recorded, Leaf minor considers as major pest of berseem and mustard, but in this climate the infestation was not severe. The average population was recorded was $0.56 /$ plant, while the maximum population was recorded after $12^{\text {th }}$ weeks. Summer, et al. (2007) recorded different species natural enemies in alfalfa agro-ecosystem associated with their hosts. Lady bird, Orius bugs, aphidlion and some hymenoptera parasitoids were the most abundant natural enemies species in alfalfa. The most abundant natural enemies were Bathyplectes curculionis, Aphidius spp., Trichogramma spp., $C$. septempunctata, Coocinella spp., Orius spp., Nabis spp. and Chrysoperla sp. Also, Alsuhaibani, (1996) reported that the alfalfa provides a large number of arthropods, some of them are pests but many have no effect on the crop. Alfalfa supports a diverse arthropod fauna, at least 1,000 species were reported on alfalfa in the US, with perhaps $100-150$ species causing injury. Few of these, however, can be described as key pest species. Mahmoud and Mohamed (2017). 
Table 2. Survey of insect pests and natural enemies associated with clover plants (Trifolium alexandrinum).

\begin{tabular}{|c|c|c|c|}
\hline Groups & Order & Family & Specie \\
\hline $\begin{array}{l}\text { Group 1 } \\
\text { (natural } \\
\text { enemies) }\end{array}$ & $\begin{array}{l}\text { Hymenoptera } \\
\text { Diptera } \\
\text { Coleoptera } \\
\text { Orthoptera }\end{array}$ & $\begin{array}{l}\text { Braconidae } \\
\text { Trichogrammaidae } \\
\text { Mantidae } \\
\text { Coccinellidae } \\
\text { Acidoidea }\end{array}$ & $\begin{array}{l}\text { Apanteles spp. } \\
\text { Trichogramma evanescens } \\
\text { Sphodromantis virides } \\
\text { Sphodromantis pioculate } \\
\text { Coccinella septempunctata } \\
\text { Coccinella undecimpunctata Eu- } \\
\text { prepocnemisplorans }\end{array}$ \\
\hline $\begin{array}{l}\text { Group } 2 \\
\text { (pests) }\end{array}$ & $\begin{array}{l}\text { Coleoptera } \\
\text { Hemiptra } \\
\text { Lepidoptera } \\
\text { Hymenoptera }\end{array}$ & $\begin{array}{l}\text { Bruchidae } \\
\text { Curculionidae } \\
\text { Pentanomidae } \\
\text { Noctudae } \\
\text { Aphididae }\end{array}$ & $\begin{array}{l}\text { Bruchidiust rifolii } \\
\text { Phytonoms bruneipennis } \\
\text { Nezara viridula } \\
\text { Spodoptera littoralis } \\
\text { Agrotis epsilon } \\
\text { Aphis gossbii }\end{array}$ \\
\hline $\begin{array}{l}\text { Group } 3 \\
\text { (Pollinators) }\end{array}$ & Coleoptera & $\begin{array}{l}\text { Sphicadae } \\
\text { Vespidae } \\
\text { Eumenidae } \\
\text { Megachilidae }\end{array}$ & $\begin{array}{l}\text { Phillianthus abdelkader } \\
\text { Polistes gallica } \\
\text { Vespa orientalis } \\
\text { Eumenus maxillosa } \\
\text { Megachile uniformis } \\
\text { Megachiles ubmucida } \\
\text { Megachile muntusemina } \\
\text { Osmia spp. } \\
\text { Chalcidoma siculum } \\
\text { Apis mellifera L. } \\
\text { Andrena spp. } \\
\text { Ocnerahis pida }\end{array}$ \\
\hline
\end{tabular}

3.2. Effect of tested compounds against bollworms Spodoptera littoralis in Egyptian clover fields.

Data in Table (3) show the percentage of infestation and reduction percent after treatment with coragen, proclaim, cord $72 \%$ EC, chlorosan and spinosad against $S$. littoralis in season (2017). Ccoragen was the superior, followed by proclaim, cord $72 \%$ EC, chlorosan while the spinosad was the laeast one. The average reduction percent values after spray were $75.8,65.9,68.7,57.3 \%$, and $52.4 \%$ for coragen, proclaim, cord, chlorosan and spinosad, respectively during the season (2017). These result were in agreement with the results reported by many workers.
Sannino and Piro (2003) stated that spinosad could be used to control $S$. littoralis, for 20 days after application. Samuel et al. (2004) tested the toxicity of spinosad against eggs, larvae, and pupae of $S$. littoralis. The results suggested that spinosad was potent compound to control $S$. littorali s. Barros et al.(2005) tested the efficiency of spinosad, and chlorpyriphos to control Spodoptera frugiperda on cotton; The treatments with spinosad were efficient in controlling $S$. frugiperda on cotton up to seven days after application. Leeuwen et al. (2006) showed that spino$\mathrm{sad}$, at $5 \mathrm{mg}$ active ingredient per plant, on third-instar larvae of $S$. littoralis killed all larvae. Also, the persistence of spinosad reached up to 45 
days after treatment under laboratory conditions. Busatos et al. (2006) showed that chlorpyrifos and spinosad were efficient in controling larvae of $S$. frugiperdaon. Randhawa et al. 2009 mentioned that spinosad was the best insecticide for the control of $H$. armigera on berseem. Also Stanley et al. (2009) decided that the H. armigera larvae were highly susceptible to spinosad and emamectin insecticides. Ahmad et al., (2006) stated that emamectin benzoate, a derivative of abamectin, is quite effective against a number of lepidopteran insect pests including Spodoptera exigua and and S.litura. Cook et al., (2004) conducted field and laboratory trials on cotton and soybean for controling the beet armyworm $S$. exigua (Hübner) and the fall armyworm Spodoptera frugiperda using indoxacarb, pyridalyl, spinosad methoxyfenozide and emamectin benzoate. Their results demonstrated good efficacy of tested compounds. Plots treated with indoxacarb, spinosad and emamectin benzoate had higher activity tward the beet armyworm larvae.

\subsection{Interspecific diversity and equitability of entomophagous after application with the tested com- pounds:}

Table (4) show the values of diversity and equitability which were calculated to embrace the way in which the individuals were distributed, the relative abundance of systemic groups after application of synthetic pesticide also the percent of stability of populations in berseem ecosystem after applying insecticide. The diversity index showed reduction in value three days after treatment, as compared to 1 and 2 weeks after treatment. The diversity index after application with proclaim and spinosad were higher as compared insecticides with chlorpyriphos, cord and coragen. The result reflected the tendency of proclaim and spinosad for selectivity when compared with the other pesticides. The highest equitability values of was in the treatment of proclaim followed by spinosad especially 3 weeks post treatment. These result were in agreement with the results reported by Hussein (1984) reported that, mixture of pesticide which produced high values of diversity and equitability in their treatments were selectivi. Heijmbroek et al. (1980) found some decrease in the diversity of species of arthropod after treatment with aldicarb. It also means that the non-target fauna groups were in their response to the treatment with Proclaim and spinosad. This reflecting a mode of organizing of entomophagouscynosis characterized by a reduced number of specific component with an equitable numerical representation of individuals. Reduction of diversity and equitability values during the intervals in the case of cord, chlorpyriphos and coragen indicated a heterogeneous distribution of individuals. The results indicated cler selectivity properties of these two insecticides. In conclusion, it could be suggested that proclaim and spinosad have toxic effect against bollworms and have a relatively selective effect on the beneficial insects in berseem. Therefore proclaim is consider a good element to here successful cotton pest integrated control. Proclaim showed toxic effect against bollworms and have a selective effect on the beneficial in- 
sects in Egyptian clover, T. alexandrinum. Therefore proclaim is also considered a good element against Egyptian clover pests. Hussein (1984) reported that, mixture of pesticide which produced high values of diversity and equitability in their treatments were selectivi. Heijmbroek et al. (1980) found some decrease in the diversity of species of arthropod after treatment with aldicarb.

\section{Conclusion}

From the previous results, it could be suggested that spinosad, and proclaim having toxic effect against bollworms and have selective effect on the beneficial insects in Berseem. Therefore present study it could be recommend using both insecticides in Berseem integrated pest control.

Table 3. Reduction\% of bollworms infestation after application with the tested insecticides on Berseem crop in Assiut region during 2017 Seasons.

\begin{tabular}{|l|c|c|c|c|c|}
\hline \multirow{2}{*}{ Insecticides } & \multicolumn{6}{|c|}{ Percent of infestation of bollworm on indicated days } & Average \\
\cline { 2 - 6 } & Pre-spray count & 7 days & 15 days & 21 days & reduction \\
\hline chlorantraniliprole & 6.0 & 3.0 & 1.0 & 3.0 & \\
& $* \mathrm{R} \%$ & 61.7 & 90.1 & 75.6 & 75.8 \\
\hline profenofos & 5.7 & 3.0 & 1.3 & 6.0 & \\
& $* \mathrm{R} \%$ & 58.6 & 86.1 & 61.4 & 68.7 \\
\hline emamectin benzoate & 5.5 & 3.5 & 1.7 & 5.0 & \\
& $* \mathrm{R} \%$ & 52.7 & 81.1 & 63.9 & 65.9 \\
\hline chloropyrifos 24\% E.C & 5.3 & 4.5 & 4.0 & 8.0 & \\
& $* \mathrm{R} \%$ & 40.7 & 65.4 & 50.9 & 57.3 \\
\hline spinosad 24 \% E.C & 5.5 & 4.0 & 5.4 & 7.0 & \\
& $* \mathrm{R} \%$ & 49.1 & 63.4 & 59.5 & 52.4 \\
\hline Control & 5.5 & 7.0 & 9.0 & 11.0 & - \\
& - & - & - & - & \\
\hline
\end{tabular}

$* \mathbf{R} \%=$ Infestation reduction percentage

Table 4. Diversity and equitability of entomophagous cyanosis after first application with the tested insecticides in Berseem field (2017).

\begin{tabular}{|c|c|c|c|c|c|c|c|c|}
\hline \multirow{3}{*}{ Insecticides } & \multirow{2}{*}{\multicolumn{2}{|c|}{ Pre-treatment }} & \multicolumn{6}{|c|}{ Post treatment intervals } \\
\hline & & & \multicolumn{2}{|c|}{7 day } & \multicolumn{2}{|c|}{15 day } & \multicolumn{2}{|c|}{ 21day } \\
\hline & $\mathrm{M}\left(\mathrm{S}^{\prime}\right)$ & $\mathrm{E}$ & $\mathrm{M}\left(\mathrm{S}^{\prime}\right)$ & $\mathrm{E}$ & $M\left(S^{\prime}\right)$ & $\mathrm{E}$ & $\mathrm{M}\left(\mathrm{S}^{\prime}\right)$ & $\mathrm{E}$ \\
\hline emamectin benzoate & 3.1 & 100 & 2.68 & 71 & 2.78 & 85 & 2.96 & 100 \\
\hline chlorantraniliprole & 3.34 & 100 & 2.7 & 72.3 & 2.75 & 75 & 2.8 & 81.9 \\
\hline profenofos & 3.39 & 100 & 2.57 & 68.3 & 2.75 & 70.2 & 2.8 & 84.1 \\
\hline chloropyrifos & 3.3 & 100 & 2.65 & 70.91 & 2.81 & 83.2 & 2.88 & 93.4 \\
\hline spinosad & 3.0 & 100 & 2.8 & 75.5 & 2.91 & 94.4 & 2.97 & 100 \\
\hline Control & 3.17 & 100 & 3.22 & 100 & 3.35 & 100 & 3.4 & 100 \\
\hline
\end{tabular}




\section{References}

Ahmad, M.; Saleem, M.A. and Sayyed, A.H. (2006). Time trend in mortality for conventional and new chemistry insecticides against leafworm, S. litura (Lepidoptera: Noctuidae). Pakistan J. biol. Sci., 9: 360-364.

Alsuhaibani, A.M. (1996). Entomofauna of alfalfa in Riyadh, Saudi Arabia, J. of King Saud Univ., 8, Agric. Sci., 2:269 - 277.

Atallah, M.A.; Kamel, E.H.; Eshba, H.M. and Ahmed, N.S.M. (1997). Insect pollinators of some field crops and their abndance in Quena region, Upper Egypt. Proc. $35^{\text {th }}$ Apimondia Congr., Belgium, 276277.

Barros, R.G.; Albernaz, K.C.; Takatsuka, F.S.; Czepak, C.; Fernandes, P.M. and Tofoli, G.R. (2005). Efficiency of insecticides in the control of $S$. frugiperda (Smith) (Lepidoptera: Noctuidae) on cotton crop. [Portuguese]. Pesquisa Agropecuaria Tropical. Universidade Federal de Goias, Escola de Agronomia e Engenharia de Alimentos, Goiania, Brazil: 35:3, 179-182. (English summary).

Bastos, C.S.; Almeida, de.; Raul, P. and Fábio, S.A. (2006). Selectivity of pesticides used on cotton (Gossypium hirsutum) to Trichogramma pretiosum reared on two laboratory -reared hosts. Pest Management Science, 62 :(1) 9198.

Cook, D. R.; Leonard, B. R. and Gore, J. (2004). Field and laboratory performance of novel insecticides against armyworms (Lepidoptera: Noctuidae). Fla Entomol 87: 43339.

Fletcher, T. B. (1919). Annonated list of Indian Crop pests. Proc $3^{\text {rd }}$ Entomol Meetings. Pusa. pp 67-68.
Hazra, C.R. and Sinha, N.C. (1996). Forage seed production- Published by South Asian Publisher Pvt. Ltd. New Delhi.

Heijbroek, W.; Vandebund, C. F.; Mass, P.W.T.; Moennount, C. A. A.; Simons, W.R. and Tichelaar, G. M. (1980). Approaches to integrated control of insect pest in Netherlands. Pudoc. wageningen 83-86.

Henderson, C.F. and Telton, E.W. (1955). Test with acaricides against the bron wheat mite. J. Econ. Entomol.48:157-161.

Hussein, S. M. (1984). Cercetari privind actiunea comuna a insecticide or in combaterea unor sppcii de daunatri. Ph.D. Thesis. Fac. Agric. Romania Bucharest. (English summary).

Iannucci, A.; DiFonzo, N. and Martiniello, P. (1996). Effects of the developmental stage at harvest on dry matter and chemical component patitioning in berseem. J. Agron. Crop Sci., 176: 165-172.

Leeuwen, T.V.; Veire, M. V.; Dermauw, W. and Tirry, L. (2006). Systemic toxicity of spinosad to the greenhouse whitefly Trialeurodes vaporariorum and to the cotton leaf worm S. littoralis. (English summary), Phytoparasitica. Priel Publishers, Rehovot, Israel: 34: 1, 102108.

Lioyd, M. and Ghelardi, R. J. (1964). A table for calculating the equitability compound of species diversity. J. Anim. Ecol. 33:217-225.

Mahmoud, S.O. and Mohamed, A. M. (2017). Survey of the Most Common Insect Species on Some Foraging Crops of Honeybees in Dakhla Oasis, New Valley Governorate, Egypt. J. Eco. Heal. Env. 5, (1), 35-40.

Qin, H.; Huang. Y. Z.; Ding, S. J. and Luo, R. (2004). The correlations of 
the different host plants with preference level, life duration and survival rate of $S$. litura Fabricius. Chinese J Eco Agric. 12: 40-42.

Randhawa, H.S.; Aulakh, S.S.; Bhagat, I. and Chhina, J.S. (2009). Efficacy of different insecticides against $H$. armigera (Hübner) (Lepidoptera: Noctuidae) on seed crop of berseem in Punjab. Legume Res., 32: 145-148.

Rueda, A. and Shelton, A.M. (1995). Onion thrips. In: Global Crop Pest. Cornell Intl. Inst. Food Agr. Dev. Cornell Univ.

Samuel, P.; Budia, F.; Schneider, M. I.; Gobbi, A.; Viñuela, E.; Valle, J. and Estal, P. D. (2004). Effects of two biorational insecticides, spinosad and methoxyfenozide, on $S$. littoralis (Lepidoptera: Noctuidae) Under Laboratory Conditions. J. Economic Entomology, 97,(6): 1906-1911.

Sannino, L. and Piro, F. (2003). Spinosad give good control of S. littoralis. informatore-Agrario. 59, 16, 65-67.

Shankarganesh, K.; Walia, S.; Dhingra, S.; Subrahmanyan, B. and Ramesh Babu, S. (2012). Effect of dihydrodillapiole on pyrethroid resistance associated esterase inhibition in an Indian population of S. litura (Fabricius). Pestic Biochem Physiol 102: 86-90.
Shannon-winner, C.L. (1959). A mathematical theory of communication, Bell, system. Tech. J. 27:379-423.

Shawer, M.; Salem M. and Saleh, R.S. (1989). Survy of insect pollinators of Egyption clover, T. alexandrinum L. at Kafr El- Sheikh, Egypt. Proc. 4 int. Conf. Apic. Trop. Climates, $134-137$.

Stanley, J.; Chanraskaran, S. and Regupathy, A.(2009). Baseline toxicity of emamectin and spinosad to $H$. armigera (Lep: Noct) for resistance monitoring. Entomol. Res., 39:321:325.

Summers, C.G.; Godfrey, L.D. and Natwick, T.E. (2007). Managing Insects in alfalfa. University of California, Division of Agriculture and Natural Resources, publication 8295, 12/2007.USA.

Tufail, A. W.; Hongxia, H. Z. and Ahmed, W.(2015). Insect Pests and Natural Enemies Associated with Berseem (T.alexandrinum L.) in Cotton Field. J. of Biology, Agriculture and Healthcare. 5, (3). 129133.

Wagan, T.A.; Khaskheli, M.I.; Abbasi, Q.D.M.; Jiskani, M. and Wagan, S.A. (2014b). Effect of Irrational Use of Pesticides on Insect Pests and Yield of Okra. J. Bio. Agri. Healthcare. (4) 25: pp. 74-78. 
تاثير بعض المبيدات على التباين النوعى والثبات البيئى للحشرات و التى تستخدم فى مكافحة دودة ورق القطن فى محصول البرسيم بمحافظة اسيوط البنى

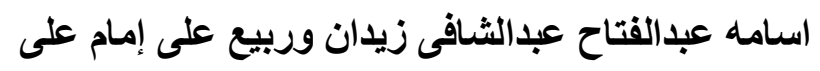

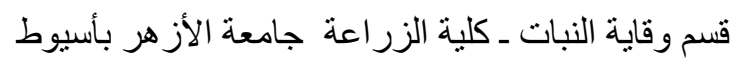

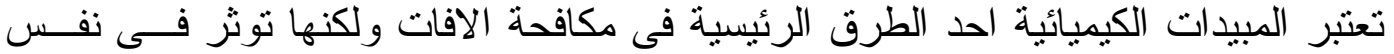

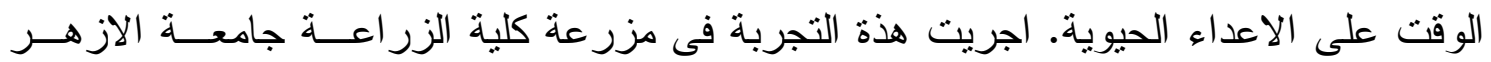

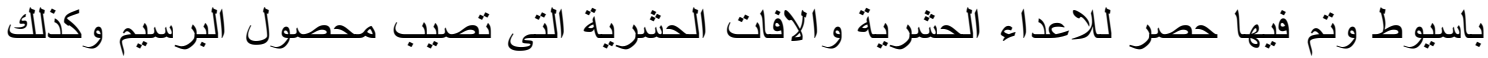

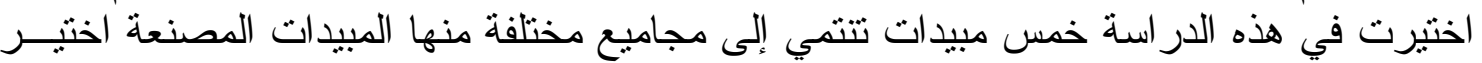

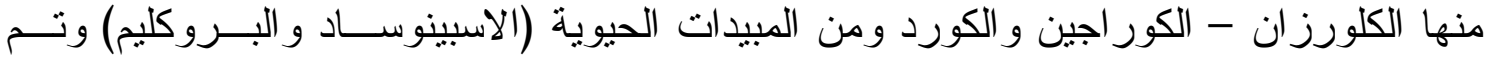

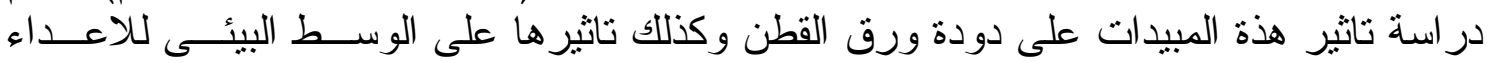
الحيوية فى الحقل وكانت النتائج كالتالى:

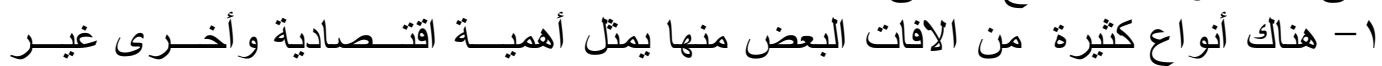

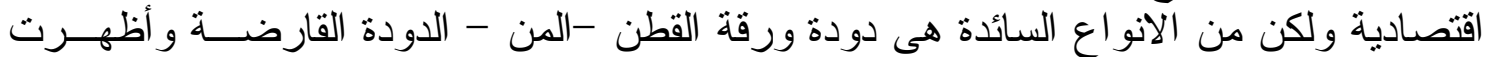

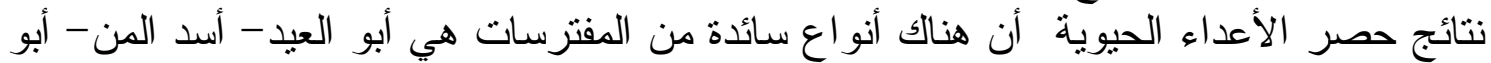

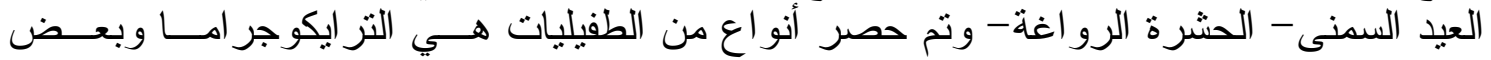

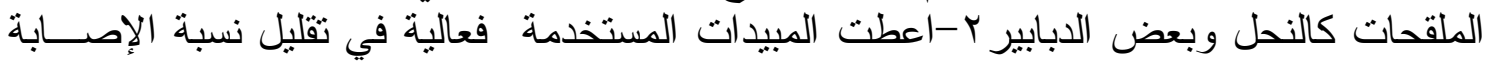

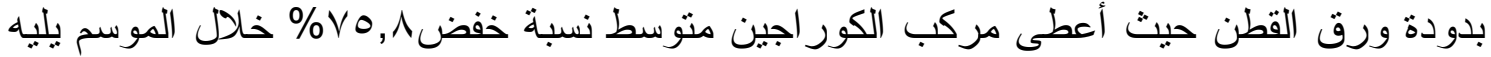

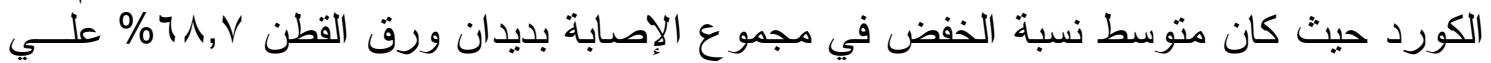

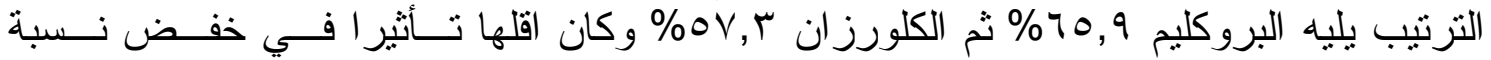

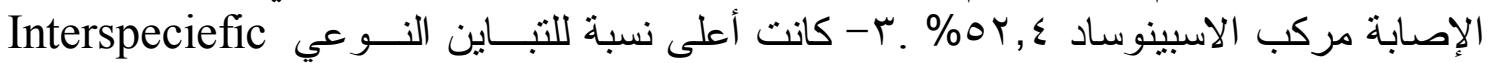
Diversity

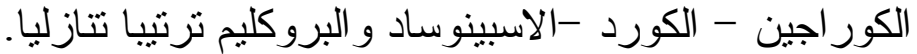
وخلصت النتائج الحقلية إلى: الكين

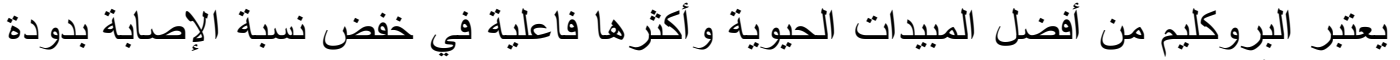

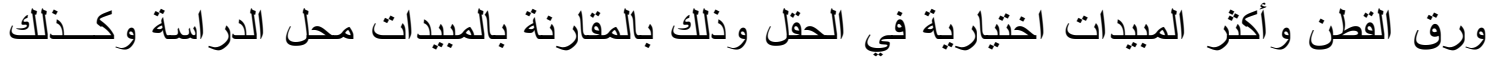

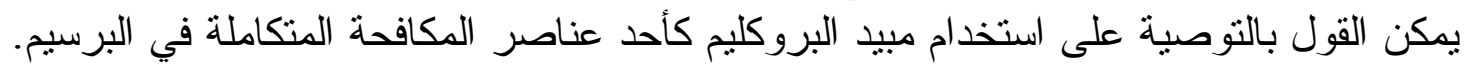

